\title{
Tingkat Kepatuhan Pasien Hipertensi terhadap Edukasi Penatalaksanaan Hipertensi oleh Petugas Kesehatan Puskesmas Abang I, Kabupaten Karangasem Bali Periode Januari-Desember 2013
}

\author{
Felix Harianto \\ Program Studi Pendidikan Dokter, Fakultas Kedokteran Universitas Udayana
}

Diterima: 4 Maret 2016. Disetujui: 28 Maret 2016. Diterbitkan: Juni 2016

\begin{abstract}
ABSTRAK
Hipertensi merupakan suatu penyakit yang memerlukan penatalaksanaan seumur hidup sehingga tekanan darah pasien hipertensi dapat terkontrol. Hal ini mengkibatkan kepatuhan pasien hipertensi dalam melaksanakan edukasi penatalaksanaan hipertensi menjadi krusial dalam proses penatalaksanaan hipertensi itu sendiri. Penelitian mengenai kepatuhan minum obat pada pasien hipertensi oleh Kenny dan Karisma pada tahun 2013 di Denpasar menunjukkan hanya 29\% sampel yang memiliki kepatuhan minum obat yang baik. Penelitian ini bertujuan untuk untuk mengetahui gambaran tingkat kepatuhan pasien hipertensi terhadap edukasi mengenai penatalaksanaan hipertensi yang diberikan oleh petugas kesehatan Puskesmas Abang I, Kabupaten Karangasem periode Januari 2013 - Desember 2013. Penelitian ini merupakan studi deskriptif kuantitatif dengan pendekatan cross sectional dengan sampel 79 pasien hipertensi di wilayah kerja Puskesmas Abang I periode Januari 2013 - Desember 2013. Data didapatkan dengan menggunakan wawancara terstruktur menggunakan kuisioner. Hasil penelitian menunjukkan masih adanya pasien yang tidak patuh terhadap edukasi mengenai konsumsi garam (29,1\%), konsumsi alkohol (10,1\%), merokok (21,5\%), melakukan aktivitas fisik (60,8\%), kontrol berobat (32,9\%), dan minum obat $(34,2 \%)$.
\end{abstract}

Kata Kunci : Penatalaksanaan Hipertensi, Tingkat Kepatuhan, Edukasi

\section{STUDY OF HYPERTENSIVE PATIENTS' COMPLIANCE TOWARDS HYPERTENSIVE MANAGEMENT ADVICE GIVEN BY MEDICAL STAFF IN ABANG I HEALTH CENTRE, KARANGASEM DISTRICT PERIOD JANUARY-DECEMBER 2013}

\begin{abstract}
Hypertension is a disease which needs a life time management so that hypertensive patients' blood pressure can be controlled. As a result, hypertensive patients' compliance towards hypertensive management advice given to them becomes a crucial thing. A study by Kenny and Karisma in 2013 about hypertensive patients compliance in taking antihypertensive drugs in Denpasar shows only $29 \%$ of all samples has a good compliance. This study aims to make an overview of hypertensive patients' compliance towards medical advice given by medical staff in Abang I health centre, Karangasem district, of January 2013 to December 2013. This is a quantitative descriptive study with a cross sectional approach with 79 samples. The samples are hypertensive patients in Abang I health centre's working area of January 2013 to December 2013. Data is obtained by a structured interview with questionnaires help. The result of this study shows there are patients that don't adhere towards medical advice about salt consumption $(29,1 \%)$, alcohol consumption $(10,1 \%)$, smoking
\end{abstract}


(21,5\%), physical activity (60,8\%), medical check-up (32,9\%), and pharmacological medication consumption (34,2\%).

Keywords : Hypertension Management, Compliance, Education

\section{PENDAHULUAN}

Hipertensi telah menjadi suatu masalah global yang terlihat dari prevalensi yang terus meningkat seiring dengan perubahan gaya hidup seperti merokok, obesitas, inaktivitas fisik, dan stress psikososial. Hipertensi dikenal juga sebagai silent killer atau pembunuh terselubung karena hipertensi tidak menimbulkan gejala atau bersifat asimtomatik. Pada umumnya, sebagian penderita tidak mengetahui bahwa dirinya menderita hipertensi. Oleh sebab itu, penyakit ini sering ditemukan secara kebetulan pada waktu penderita datang ke dokter untuk memeriksa penyakit lain. ${ }^{1}$

Hampir di setiap negara, hipertensi menduduki peringkat pertama sebagai penyakit yang paling sering dijumpai. Hipertensi didefinisikan sebagai peningkatan tekanan darah persisten dimana tekanan sistoliknya di atas 140 $\mathrm{mmHg}$ dan tekanan diastolik diatas $90 \mathrm{mmHg}$. Dalam kriteria tekanan darah menurut JNC 7 di bagi menjadi 4 kategori ,yaitu normal, prehipertensi, hipertensi derajat 1 , dan hipertensi derajat 2. ${ }^{2,3}$

Hipertensi merupakan penyebab kesakitan dan kematian yang tinggi di seluruh dunia. Di indonesia saat ini, angka kematian karena hipertensi sangat tinggi. Hipertensi merupakan penyebab kematian nomor 3 setelah stroke dan tuberkulosis, yakni mencapai $6,7 \%$ dari populasi kematian pada semua umur di Indonesia. ${ }^{4}$ Hasil Riset Kesehatan Dasar (Riskesdas) Balitbangkes tahun 2007 menunjukan prevalensi hipertensi secara nasional mencapai $31,7 \%{ }^{5}$ Dari jumlah itu, 60\% penderita hipertensi berakhir pada stroke. Sedangkan sisanya pada penyakit jantung, gagal ginjal, dan kebutaan. ${ }^{3,4}$

Puskesmas Abang I merupakan salah satu Puskesmas yang terdapat di Kecamatan Abang, Kabupaten Karangasem. Hipertensi ternyata juga menjadi masalah kesehatan utama di Puskesmas Abang I. Berdasarkan data kunjungan pada tahun 2013, hipertensi termasuk dalam 10 penyakit terbanyak di wilayah kerja Puskesmas Abang I, yakni menempati urutan ke lima dengan jumlah
836 kasus. Dari 836 kunjungan, pasien yang mengalami hipertensi berjumlah 230 orang, ini menandakan bahwa pasien berkunjung lebih dari satu kali. Dengan jumlah pasien laki-laki sebanyak 115 orang dan perempuan 115 orang. Jumlah tersebut mengalami peningkatan sejak tahun 2011 yang berdasarkan data yang tersedia di Puskesmas Abang I, pada tahun 2011 terdapat 480 kasus yang berkunjung ke Puskesmas Abang I dan pada tahun 2012 sebanyak 513 kasus yang berkunjung ke Puskesmas Abang I. Pada kedua tahun tersebut, hipertensi tidak memasuki 10 penyakit terbanyak. ${ }^{6}$

Hipertensi merupakan suatu penyakit yang memerlukan penatalaksanaan seumur hidup sehingga tekanan darah pasien dapat terkontrol. Secara garis besar, terdapat 2 metode penatalaksanaan hipertensi yakni melalui modifikasi gaya hidup serta farmakologi. ${ }^{7,8}$ Mengingat penatalaksanaan hipertensi yang bersifat seumur hidup, maka kepatuhan pasien hipertensi dalam menjalankan edukasi yang diberikan oleh petugas kesehatan menjadi hal yang krusial dalam menjaga tekanan darah mereka tetap terkontrol. Penelitian mengenai kepatuhan minum obat pada pasien hipertensi pernah dilakukan oleh Evadewi dan Sukmayanti pada tahun 2013 di Denpasar. Hasil penelitian mereka menunjukkan hanya $29 \%$ sampel yang memiliki kepatuhan minum obat yang baik. ${ }^{6,9,10}$

Tidak ada data mengenai tingkat kepatuhan pasien hipertensi di wilayah kerja Puskesmas Abang I serta berdasarkan hasil dari observasi serta wawancara beberapa pasien hipertensi poliklinik umum, pasien hipertensi hanya mendapatkan informasi penatalaksanaan hipertensi dari petugas puskesmas ketika mereka datang untuk kontrol berobat. Metode edukasi yang seperti ini memiliki kelemahan berupa lamanya waktu di antara kontrol berobat yang bisa berjarak seminggu bahkan sampai sebulan sehingga ketidakpatuhan terhadap edukasi sangatlah mungkin terjadi. Berdasarkan permasalahan di atas, maka kami melakukan penelitian untuk mengetahui gambaran 
tingkat kepatuhan pasien hipertensi terhadap edukasi mengenai penatalaksanaan hipertensi yang diberikan oleh petugas kesehatan Puskesmas Abang I, Kabupaten Karangasem Periode Januari 2013 - Desember 2013.

\section{BAHAN DAN METODE}

Penelitian ini merupakan studi deskriptif kuantitatif dengan pendekatan cross sectional yang dilakukan satu kali pengumpulan data untuk mengetahui gambaran tingkat kepatuhan penderita hipertensi terhadap edukasi yang diberikan oleh petugas kesehatan Puskesmas Abang | Karangasem periode Januari 2013 Desember 2013. Penelitian ini dilakukan di wilayah kerja Puskesmas Abang I Karangasem pada tanggal 29 September 2014 sampai dengan 4 Oktober 2014. Populasi dalam penelitian ini adalah seluruh pasien yang didiagnosis hipertensi yang datang ke Puskesmas Abang I dari bulan Januari 2013 Desember 2013. Populasi diambil berdasarkan data register pelayanan rawat jalan Puskesmas Abang I bulan Januari 2013 - Desember tahun 2013. Sebagai sampel adalah pasien yang didiagnosis hipertensi di Puskesmas Abang 1 selama Januari 2013 - Desember 2013 yang masuk ke dalam kriteria inklusi dan tidak masuk kriteria ekslusi. Berdasarkan perhitungan rumus didapatkan sampel minimal sebanyak 79 orang. Untuk mempermudah perhitungan, peneliti menetapkan menjadi 80 sampel. Pengambilan sampel dilakukan melalui beberapa tahap yaitu: (1) Pada wilayah kerja Puskesmas Abang I terdapat 8 desa yaitu: Desa Abang, Desa Ababi, Desa Tiyingtali, Desa Pidpid, Desa Nawakerti, Desa Kesimpar, Desa Tista, dan Desa Tribuana. (2) Berdasarkan data register Puskesmas Abang I periode Januari-Desember 2013 didapatkan 230 pasien hipertensi sebagai sample frame. Kemudian dibuat daftar sample frame dan diberi nomor dari 1 sampai 230. (3) Dipilih secara acak angka dari 1 sampai 6 kemudian angka yang terpilih akan dijadikan interval daftar sample frame untuk pemilihan sampel, contohnya bila terpilih angka 5 maka akan dipilih sampel no 1 kemudian 6 kemudian 11 dan seterusnya sampai tercapai 79 sampel.

Pengumpulan data dilakukan dengan cara wawancara terstruktur melalui kuisioner dari rumah ke rumah. Sebelum wawancara dilakukan responden diminta persetujuan terlebih dahulu merujuk pada prinsip dan etika penelitian kedokteran. Data yang telah dikumpulkan oleh peneliti kemudian dianalisis dan diolah dengan menggunakan program komputer meliputiediting, coding, entry dan tabulasi.

\section{HASIL PENELITIAN}

\section{Karakteristik Responden}

Penelitian dilakukan terhadap 79 sampel pasien hipertensi yang didiagnosis di Puskesmas Abang I selama periode Januari-Desember 2013. Sampel bertempat tinggal di wilayah kerja Puskesmas Abang I. Dari sejumlah responden yang terpilih, seluruhnya menyatakan bersedia untuk ikut serta di dalam penelitian ini.

Pengumpulan data dilaksanakan dari tanggal 30 September sampai 15 Oktober 2014. Wawancara dilakukan oleh tiga orang mahasiswa dan dilakukan dengan mengunjungi rumah responden. Dari 79 responden yang telah diwawancarai, diperoleh karakteristik penduduk meliputi umur, jenis kelamin, dan tingkat pendidikan

Tabel 1. Karakteristik Responden

\begin{tabular}{llcc}
\hline Karakteristik Responden & Jumlah & $\begin{array}{c}\text { Persentase } \\
\text { (\%) }\end{array}$ \\
\hline Umur & $\begin{array}{l}26-35 \\
\text { tahun }\end{array}$ & 3 & 8,9 \\
\hline & $\begin{array}{l}36-45 \\
\text { tahun }\end{array}$ & 7 & 3,8 \\
& $\begin{array}{l}46-55 \\
\text { tahun }\end{array}$ & 18 & 22,8 \\
& $\begin{array}{l}56-65 \\
\text { tahun }\end{array}$ & 24 & 30,4 \\
\hline & & & \\
\hline Jenis & Laki - laki & 35 & 44,3
\end{tabular}




\section{Kelamin}

\begin{tabular}{|c|c|c|c|}
\hline & $\begin{array}{l}26-35 \\
\text { tahun }\end{array}$ & 3 & 3,8 \\
\hline & $\begin{array}{l}36-45 \\
\text { tahun }\end{array}$ & 0 & 0 \\
\hline & $\begin{array}{l}46-55 \\
\text { tahun }\end{array}$ & 9 & 11,4 \\
\hline & $\begin{array}{l}56-65 \\
\text { tahun }\end{array}$ & 11 & 13,9 \\
\hline & $\geq 66$ tahun & 12 & 15,2 \\
\hline & $\begin{array}{l}\text { Perempua } \\
\mathrm{n}\end{array}$ & 44 & 55,7 \\
\hline & $\begin{array}{l}26-35 \\
\text { tahun }\end{array}$ & 0 & 0 \\
\hline & $\begin{array}{l}36-45 \\
\text { tahun }\end{array}$ & 7 & 8,9 \\
\hline & $\begin{array}{l}46-55 \\
\text { tahun }\end{array}$ & 9 & 11,4 \\
\hline & $\begin{array}{l}56-65 \\
\text { tahun }\end{array}$ & 13 & 16,5 \\
\hline & $\geq 66$ tahun & 15 & 19 \\
\hline $\begin{array}{l}\text { Tingkat } \\
\text { Pendidikan }\end{array}$ & $\begin{array}{l}\text { Tidak } \\
\text { sekolah }\end{array}$ & 7 & 8,9 \\
\hline & $\begin{array}{l}\text { Tamat SD } \\
\text { atau } \\
\text { sederajat }\end{array}$ & 41 & 51,9 \\
\hline & $\begin{array}{l}\text { Tamat } \\
\text { SMP atau } \\
\text { sederajat }\end{array}$ & 12 & 15,2 \\
\hline & $\begin{array}{l}\text { Tamat } \\
\text { SMA atau } \\
\text { sederajat }\end{array}$ & 16 & 20,3 \\
\hline & $\begin{array}{l}\text { Tamat } \\
\text { Perguruan } \\
\text { Tinggi }\end{array}$ & 3 & 3,8 \\
\hline
\end{tabular}

Dari data yang diperoleh, responden lebih banyak pada kelompok usia >65 tahun (manula) sebanyak 27 orang $(30,4 \%)$ dan lebih banyak berjenis kelamin perempuan $(55,7 \%)$. Mayoritas pendidikan terakhir adalah tamat SD atau sederajat sejumlah 41 orang $(51,9 \%)$.

\section{Distribusi Tingkat Kepatuhan Konsumsi Garam Pada Pasien Hipertensi}

Tabel 2. Distribusi Tingkat Kepatuhan Konsumsi Garam

\begin{tabular}{lccc} 
& \multicolumn{2}{c}{ Jenis Kelamin } & Total \\
\cline { 2 - 3 } & $\begin{array}{c}\text { Laki - } \\
\text { laki }\end{array}$ & Perempuan & \\
\hline $\begin{array}{l}\text { Melebihi } \\
\text { batas untuk } \\
\text { pasien } \\
\text { hipertensi }\end{array}$ & 7 & 16 & 23 \\
\hline \% & 20 & 36,4 & \\
\hline $\begin{array}{l}\text { Dalam } \\
\text { batas untuk } \\
\text { pasien } \\
\text { hipertensi }\end{array}$ & 28 & 28,1 \\
\hline \% & 80 & 63,6 & 56 \\
\hline Total & 35 & 44 & 79 \\
\hline \% & 100 & 100 & 100 \\
\hline
\end{tabular}

Dari 79 responden yang di wawancara, sebanyak 23 responden atau 29,1\% mengkonsumsi garam melebihi batas untuk pasien hipertensi, terdiri dari 7 laki - laki (20\%) dan 16 perempuan $(36,4 \%)$. Sedangkan yang mengkonsumsi garam dalam batas untuk pasien hipertensi sebanyak 56 orang $(70,9 \%)$, terdiri dari 28 orang laki-laki $(80 \%)$ dan 28 orang perempuan $(63,6 \%)$.

\section{Distribusi Tingkat Kepatuhan Konsumsi Alkohol Pada Pasien Hipertensi}


Tabel 3. Distribusi Tingkat Kepatuhan Konsumsi Alkohol

\begin{tabular}{|c|c|c|c|}
\hline & \multicolumn{2}{|c|}{ Jenis Kelamin } & \multirow[t]{2}{*}{ Total } \\
\hline & $\begin{array}{c}\text { Laki - } \\
\text { laki }\end{array}$ & Perempuan & \\
\hline $\begin{array}{l}\text { Melebihi } \\
\text { batas untuk } \\
\text { pasien } \\
\text { hipertensi }\end{array}$ & 8 & 0 & 8 \\
\hline$\%$ & 22,9 & 0 & 10,1 \\
\hline $\begin{array}{l}\text { Dalam } \\
\text { batas untuk } \\
\text { pasien } \\
\text { hipertensi }\end{array}$ & 27 & 44 & 71 \\
\hline$\%$ & 77,1 & 100 & 89,9 \\
\hline Total & 35 & 44 & 79 \\
\hline$\%$ & 100 & 100 & 100 \\
\hline
\end{tabular}

Dari 79 responden yang di wawancara, sebanyak 8 responden atau 10,1\% mengkonsumsi alkohol melebihi batas untuk pasien hipertensi dimana semuanya terdiri dari laki - laki (22,9\%). Sedangkan yang mengkonsumsi alkohol dalam batas untuk pasien hipertensi sebanyak 71 orang $(89,9 \%)$, terdiri dari 27 orang laki-laki $(77,1 \%)$ dan 44 orang perempuan (100\%).

\section{Distribusi Tingkat Kepatuhan Merokok Pada Pasien Hipertensi}

Tabel 4. Distribusi Tingkat Kepatuhan Merokok

\begin{tabular}{cccc}
\hline & \multicolumn{2}{c}{ Jenis Kelamin } & Total \\
\cline { 2 - 3 } & $\begin{array}{c}\text { Laki - } \\
\text { laki }\end{array}$ & Perempuan & \\
\hline Merokok & 16 & 1 & 17 \\
\hline$\%$ & 45,7 & 2,3 & 21,5 \\
\hline $\begin{array}{l}\text { Tidak } \\
\text { merokok }\end{array}$ & 19 & 43 & 62 \\
\hline
\end{tabular}

\begin{tabular}{cccc}
\hline$\%$ & 54,3 & 97,7 & 78,5 \\
\hline Total & 35 & 44 & 79 \\
\hline$\%$ & 100 & 100 & 100 \\
\hline
\end{tabular}

Dari 79 responden yang di wawancara, sebanyak 17 responden atau 21,5\% merokok terdiri dari 16 orang laki - laki $(45,7 \%)$ dan 1 (2,3\%) orang perempuan. Sedangkan yang tidak merokok sebanyak 62 orang $(78,5 \%)$, terdiri dari 19 orang laki-laki $(54,3 \%)$ dan 43 orang perempuan $(97,7 \%)$.

\section{Distribusi Tingkat Kepatuhan Melakukan Aktivitas Fisik Pada Pasien Hipertensi}

Tabel 5. Distribusi Tingkat Kepatuhan Melakukan Aktivitas Fisik

\begin{tabular}{cccc}
\hline & \multicolumn{2}{c}{ Jenis Kelamin } & Total \\
\cline { 2 - 3 } & $\begin{array}{c}\text { Laki - } \\
\text { laki }\end{array}$ & Perempuan & \\
\hline $\begin{array}{l}\text { Tidak } \\
\text { melakukan } \\
\text { aktivitas fisik }\end{array}$ & 15 & 33 & 48 \\
\hline \% & 42,9 & 75 & \\
\hline $\begin{array}{c}\text { Melakukan } \\
\text { aktivitas fisik }\end{array}$ & 20 & 11 & 31 \\
\hline \% & 57,1 & 25 & 39,2 \\
\hline Total & 35 & 44 & 79 \\
\hline \% & 100 & 100 & 100 \\
\hline
\end{tabular}

Dari 79 responden yang di wawancara, sebanyak 48 responden atau $60,8 \%$ tidak melakukan aktivitas fisik minimal 30 menit terdiri dari 15 orang laki - laki $(42,9 \%)$ dan 33 orang perempuan (75\%). Sedangkan yang melakukan aktivitas fisik minimal 30 menit sebanyak 31 orang $(39,2 \%)$, terdiri dari 20 orang laki-laki $(57,1 \%)$ dan 11 orang perempuan (25\%). 


\section{Distribusi Tingkat Kepatuhan Kontrol Berobat Pada Pasien Hipertensi}

Tabel 6. Distribusi Tingkat Kepatuhan Kontrol Berobat

\begin{tabular}{cccc} 
& \multicolumn{2}{c}{ Jenis Kelamin } & Total \\
\cline { 2 - 3 } & $\begin{array}{c}\text { Laki }- \\
\text { laki }\end{array}$ & Perempuan & \\
\cline { 1 - 2 } $\begin{array}{c}\text { Tidak rutin } \\
\text { kontrol } \\
\text { berobat }\end{array}$ & 15 & 11 & 26 \\
\hline$\%$ & 42,9 & 25 & 32,9 \\
\hline $\begin{array}{c}\text { Rutin } \\
\text { kontrol } \\
\text { berobat }\end{array}$ & 20 & 33 & 53 \\
\hline$\%$ & 57,1 & 75 & 67,1 \\
\hline Total & 35 & 44 & 79 \\
\hline$\%$ & 100 & 100 & 100 \\
\hline
\end{tabular}

Dari 79 responden yang di wawancara, sebanyak 26 responden atau 32,9\% tidak rutin kontrol berobat terdiri dari 15 orang laki - laki $(42,9 \%)$ dan 11 orang perempuan (25\%). Sedangkan yang rutin kontrol berobat sebanyak 53 orang $(67,1 \%)$, terdiri dari 20 orang laki-laki $(57,1 \%)$ dan 33 orang perempuan (75\%).

\section{Distribusi Tingkat Kepatuhan Minum Obat Pada Pasien Hipertensi}

Tabel 7. Distribusi Tingkat Kepatuhan Minum Obat

$$
\text { Jenis Kelamin Total }
$$

Laki - Perempuan
laki

\begin{tabular}{llll}
\hline Tidak & 16 & 11 & 27 \\
rutin & & & \\
minum & & & \\
obat & & &
\end{tabular}

\begin{tabular}{cccc}
\hline$\%$ & 45,7 & 25 & 34,2 \\
\hline $\begin{array}{c}\text { Rutin } \\
\text { minum } \\
\text { obat }\end{array}$ & 19 & 33 & 52 \\
\hline$\%$ & 54,3 & 75 & 65,8 \\
\hline Total & 35 & 44 & 79 \\
\hline$\%$ & 100 & 100 & 100 \\
\hline
\end{tabular}

Dari 79 responden yang di wawancara, sebanyak 27 responden atau $34,2 \%$ tidak rutin minum obat terdiri dari 16 orang laki - laki $(45,7 \%)$ dan 11 orang perempuan (25\%). Sedangkan yang rutin minum obat sebanyak 52 orang $(65,8 \%)$, terdiri dari 19 orang laki-laki (54,3\%) dan 33 orang perempuan (75\%).

\section{PEMBAHASAN}

Distribusi Tingkat Kepatuhan Penatalaksanaan Hipertensi Berdasarkan Jenis Kelamin

Penelitian oleh Evadewi dan Sukmayanti pada tahun 2013 menunjukkan subyek dengan jenis kelamin laki - laki maupun perempuan lebih banyak yang tidak patuh dalam mengonsumsi obat. Walaupun jumlah subyek laki - laki lebih banyak yang tidak mematuhi proses pengobatan. Hal ini dikarenakan faktor gaya hidup laki - laki usia dewasa yang cenderung kurang mempedulikan kesehatan. Pada penelitian ini ditemukan hasil yang serupa berupa persentase laki - laki yang tidak patuh minum obat lebih tinggi dari persentase perempuan. Hasil ini juga terjadi pada kategori kepatuhan mengenai konsumsi alkohol, merokok, serta rutinitas kontrol berobat. Namun pada kategori kepatuhan mengenai konsumsi garam dan aktivitas fisik, persentasi laki - laki yang patuh lebih tinggi daripada persentase perempuan. $^{3}$

Distribusi Tingkat Kepatuhan Konsumsi Garam Pada Pasien Hipertensi

Diet tinggi garam dihubungkan dengan peningkatan tekanan darah dan prevalensi hipertensi. ${ }^{1}$ Penelitian oleh Ohta menunjukkan 
tingkat kepatuhan yang rendah dalam diet rendah garam bagi pasien hipertensi di Jepang. Hal ini dikarenakan adanya perubahan gaya hidup menjadi seperti di barat seperti kebiasaan makan di luar rumah dan makan makanan cepat saji. Fenomena ini terutama terjadi pada orang yang memiliki pekerjaan tetap yang meningkatkan kemungkinan makan makanan di luar. ${ }^{4}$ Penelitian ini menunjukkan adanya pasien yang mengkonsumsi garam melebihi batas untuk pasien hipertensi sebanyak 23 responden (29,1\%).

\section{Distribusi Tingkat Kepatuhan Konsumsi Alkohol Pada Pasien Hipertensi}

Alkohol bila diminum melebihi batas yang ditentukan untuk pasien hipertensi memiliki dampak untuk menaikkan tekanan darah. ${ }^{1}$ Dalam penelitian ini hanya 8 responden $(10,1 \%)$ yang mengkonsumsi alkohol melebihi batas untuk pasien hipertensi.

\section{Distribusi Tingkat Kepatuhan Merokok Pada Pasien Hipertensi}

Rokok akan mengakibatkan vasokonstriksi pembuluh darah perifer dan pembuluh di ginjal sehingga terjadi peningkatan tekanan darah. ${ }^{1}$ Penelitian oleh Heimann menunjukkan 13\% responden dari 1125 pasien tidak patuh dalam hal larangan merokok. Hal ini diakibatkan pada susahnya untuk merubah kebiasaan merokok serta kurangnya informasi dalam hal larangan merokok. ${ }^{6}$ Pada penelitian ini didapatkan 17 responden atau $21,5 \%$ dari total responden yang merokok.

\section{Distribusi Tingkat Kepatuhan Melakukan Aktivitas Fisik Pada Pasien Hipertensi}

Olahraga lebih banyak dihubungkan dengan pengobatan hipertensi karena olahraga aerobik (seperti bersepeda, jogging) yang teratur dapat menurunkan tahanan perifer yang akan dapat menurunkan tekanan darah. ${ }^{1,2}$ Penelitian oleh Mahmoud menunjukkan 796 responden (88,4\%) dari total 900 responden tidak patuh untuk melakukan aktivitas fisik. Hal ini diakibatkan karena kurangnya pengetahuan mengenai pentingnya aktivitas fisik bagi pasien hipertensi, kesulitan memulai kebiasaan melakukan aktivitas fisik, adanya pekerjaan sehari - hari yang menyita waktu, serta adanya kondisi fisik yang menghalangi seseorang untuk melakukan aktivitas fisik. ${ }^{5,6} \mathrm{Hal}$ ini sejalan dengan hasil yang didapatkan dalam penelitian ini yakni sebanyak 48 responden $(60,8 \%)$ tidak melakukan aktivitas fisik sekurang kurangnya 30 menit dalam sehari.

\section{Distribusi Tingkat Kepatuhan Kontrol Berobat Pada Pasien Hipertensi}

Seperti telah disebutkan sebelumnya, hipertensi membutuhkan penatalaksanaan yang seumur hidup sehingga rutin kontrol berobat menjadi krusial dalam menjaga tekanan darah pasien hipertensi tetap terkontrol. ${ }^{1}$ Penelitian oleh Mahmoud menunjukkan 591 responden (65,7\%) dari 900 responden tidak rutin kontrol berobat. Hal ini diakibatkan karena pasien tidak memiliki motivasi untuk rutin kontrol berobat karena tidak merasakan gejala apa - apa serta adanya masalah finansial. ${ }^{1,3}$ Penelitian ini menunjukkan masih adanya pasien yang tidak rutin kontrol berobat sebanyak 26 responden (32,9\%).

\section{Distribusi Tingkat Kepatuhan Minum Obat Pada Pasien Hipertensi}

Farmakologi merupakan salah satu metode untuk penatalaksanaan hipertensi. ${ }^{1,8}$ Penelitian oleh Mahmoud menunjukkan 699 responden $(77,7 \%)$ dari 900 responden tidak rutin minum obat. Hal ini diakibatkan karena pasien tidak memiliki motivasi untuk rutin minum obat karena tidak merasakan gejala apa - apa, lupa dengan jadwal minum obat, serta adanya masalah finansial. ${ }^{3}$ Penelitian ini menunjukkan masih ada nya pasien yang tidak rutin minum obat sebanyak 27 responden $(34,2 \%)$.

\section{Kelemahan Penelitian}

Kelemahan daripada penelitian ini ialah proses pengambilan data yang berupa wawancara dengan menggunakan alat berupa kuisioner. Kemungkinan terjadinya bias sangatlah tinggi dikarenakan pada saat wawancara dilakukan, subyek mungkin ingin terlihat sebagai individu yang peduli terhadap kesehatannya sehingga subyek menjawab patuh. Hal ini tercermin dari hasil penelitian yang menunjukkan persentase subyek yang patuh dalam kategori konsumsi garam, konsumsi alkohol, merokok, kontrol berobat, serta minum obat lebih 
tinggi daripada persentase subyek yang tidak patuh. Hanya kategori kepatuhan dalam aktivitas fisik yang menunjukkan persentase subyek yang tidak patuh lebih tinggi dari persentase subyek yang patuh.

Kelemahan lain dari penelitian ini ialah alat pengambilan data berupa kuisioner yang menggunakan pertanyaan tertutup dengan jawaban berupa iya atau tidak. Kemungkinan terjadinya kesalahan dalam intrepetasi jawaban sangat tinggi karena subyek hanya dibatasi jawabannya berupa iya atau tidak. Serta metode pengambilan data yang seperti ini sangatlah tergantung pada subyek sehingga kurang obyektif.

\section{SIMPULAN}

Dari penelitian dan pembahasan dapat disimpulkan hal-hal sebagai berikut: (1) Kejadian hipertensi lebih banyak dialami pada umur $\geq 66$ tahun sebesar $34,2 \%$, perempuan dengan umur $\geq$ 66 tahun sebesar 55,6\%, serta dengan tingkat pendidikan tamat SD atau sederajat sebesar 51,9\%. (2) Peneliti melihat masih adanya pasien hipertensi di wilayah kerja Puskesmas Abang I periode Januari 2013 - Desember 2013 yang tidak patuh dalam menjalankan edukasi penatalaksanaan hipertensi dalam hal konsumsi garam, konsumsi makanan dengan kandungan lemak tinggi, konsumsi alkohol, merokok, beraktivitas fisik, kontrol berobat, dan minum obat. (3) Pada kategori kepatuhan mengenai konsumsi alkohol, merokok, rutinitas kontrol berobat dan minum obat, persentase laki - laki yang tidak patuh lebih tinggi daripada persentase perempuan.. Namun pada kategori kepatuhan mengenai konsumsi garam dan aktivitas fisik, persentase laki - laki yang patuh lebih tinggi daripada persentase perempuan.

\section{SARAN}

Dari penelitian dan pembahasan dapat dirumuskan saran untuk penelitian berikutnya sebagai berikut: (1) Perlu adanya suatu program untuk penatalaksanaan hipertensi yang sesuai untuk masyarakat manula mengingat golongan manula menduduki peringkat tertinggi untuk pasien hipertensi. (2) Perlu adanya suatu penggunaan metode yang obyektif dalam hal pengambilan data dari responden sehingga data yang ada tidak bias apabila akan diadakan penelitian yang lebih lanjut.

\section{DAFTAR PUSTAKA}

1. WHO. 2013. A global brief on Hypertension

2. Appel LJ, Brands MW, et al. 2006. Dietary Approaches to Prevent and Treat Hypertension A Scientific Statement From the American Heart Association. Hypertension. 47:296-308.

3. Binongko A. $2010 . \quad$ Hipertensi Epidemiologi Penyakit Tidak Menular.

4. Evadewi PTR, Sukmayanti LMK. 2013. Kepatuhan Mengonsumsi Obat Pasien Hipertensi Di Denpasar Ditinjau Dari Kepribadian Tipe $A$ dan Tipe $B$. Jurnal Psikologi Udayana. 1(1):32-42.

5. Gormer B. 2007. Farmakologi Hipertensi.

6. Heymann AD, Gross R, et al. 2011. Factors Associated with Hypertensive Patients' Compliance with Recommended Lifestyle Behaviors. IMAJ. 13:553-557.

7. Mahmoud MIH. 2012. Compliance with Treatment of Patients with Hypertension in Almadinah Almunawwarah: $A$ communitiy-based study. Journal of Taibah University Medical Sciences. 7(2):92-98.

8. Martin J. 2008. Hypertension Guidelines: Revisiting The JNC 7 Recommendations. The Journal of Lancaster General Hospital. 3(3):91-97.

9. Mohammed AR. 2013. Hypertension. Available at: www.clevelandclinicmeded.com/medical pubs/diseasemanagement/nephrology/ar terial-hypertension/. Akses: 10 Oktober 2014.

10. Ohta Y, Tsuchihashi T, et al. 2005. LongTerm Compliance with Salt Restriction in Japanese Hypertensive Patients. Hypertens Res. 28(12):953-957.

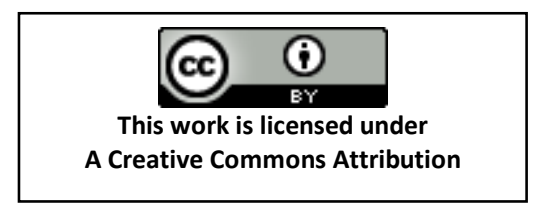

http://intisarisainsmedis.weebly.com/ 
